„Bohemistyka” 2017, nr 1, ISSN 1642-9893

\title{
Demiurgiczne wymiary rzeczywistości. Na marginesie powieści Alfreda Kubina i Jana Weissa
}

Keywords: novel, literary space, Alfred Kubin, Jan Weiss, Gnosticism Słowa kluczowe: powieść, przestrzeń literacka, Alfred Kubin, Jan Weiss, gnostycyzm

\section{Abstract}

The paper discusses certain motifs common to the novels of Alfred Kubin and Jan Weiss. The author analyses symbolic domains of the plot, referring among others to the gnostic thought, the theory of utopia, or psychoanalysis. She emphasises the intertextuality of the novels discussed, which constitutes a kind of a game with the recipient in which the authors demonstrate the demiurgical aspects of reality.

Artykuł przedstawia wspólne motywy powieści Alfreda Kubina i Jana Weissa. Autorka analizuje przestrzenie symboliczne fabuły, odwołując się m.in. do myśli gnostyckiej, torii utopii, psychoanalizy. Zwraca uwage na intertekstualność omawianych powieści, będącą swego rodzaju grą z odbiorcą, poprzez którą obaj autorzy ukazują demiurgiczne wymiary rzeczywistości.

Lubomír Doležel, piszac o literaturze XX wieku, stwierdza, iż człowiek nie żyje w świecie, który sam tworzy, ale otoczony jest i zmanipulowany przez ukryte, niewidzialne siły. Siły te nie są już, jak w dawnych opowieściach i mitach, o proweniencji nadprzyrodzonej, boskiej, czy demonicznej, stanowią raczej reprezentacje naturalnych sił ludzkiej psyche lub organizacji społecznych - w obu tych przypadkach mają tak samo despotyczny i niszczący charakter (Doležel 2008, s. 71-72). Absolutyzm rzeczywistości, w takim znaczeniu, o jakim pisze Hans Blumenberg (Blumenberg 2009, s. 3), zostaje więc wyparty przez podejście czysto racjonalne, empiryczne, wynikiem czego jest 
kształtowanie się licznych modeli światów alternatywnych opartych na fundamentach już istniejących, jednak kształtujących rzeczywistość utopijną, bądź odwrotnie - demaskujących jej negatywne strony. Pisarze powołują do istnienia krainy w pierwotnym zamierzeniu doskonałe, odpowiadające wszystkim wymaganiom i potrzebom zamieszkujących je społeczności. Te, po częstokroć demiurgiczne, kreacje napędza potrzeba ciągłej zmiany, ulepszania tego, co zastane, statyczne, przestarzałe. Owa potrzeba stworzenia świata doskonałego pcha ludzkość, już od jej początków, do formowania coraz to nowych wymiarów realności. Czy jednak można stworzyć świat idealny, utopijny, nie przenosząc na niego wszystkich negatywnych wzorców i zachowań ludzkich? Wielu twórców, pisarzy i filozofów, zdaje się w to wątpić. Nietzsche pisze w Woli mocy o biernym nihiliście, który „sądzi o świecie, jaki jest, że być nie powinien, a o świecie, jaki być powinien, że nie egzystuje" (Nietzsche 1911, s. 323). Tego rodzaju powątpiewania w możliwość stworzenia państwa lub ustroju doskonałego znajdują swoje odzwierciedlenie w literaturze o charakterze antyutopijnym, w której rzeczywistość poddana zostaje przez pisarzy szczegółowej dekonstrukcji w celu wskazania braków i niemożliwość egzystencji tego typu światów lub zagrożeń wypływających z np. postępu technicznego i cywilizacyjnego.

Celem niniejszego artykułu jest przedstawienie pewnych wspólnych motywów, które budują świat przedstawiony w dwóch powieściach, mianowicie mowa o utworach Alfreda Kubina Die andere Seite (1909, pol. wyd. 1968 zatytułowane Po tamtej stronie) oraz Jana Weissa Dìm o 1000 patrech (1929, pol. wyd. 1960 zatytułowane Mullerdom ma tysiac pięter). Powieści te reprezentują swego rodzaju rzeczywistość symboliczną, której zadaniem jest łączenie świadomego i nieświadomego, tego, co realne i nierealne. ,Rzeczywistość symboliczna jest drogą, procesem wiodącym do rzeczywistości transcendentnej” (Piróg 1999, s. 76), należałoby jeszcze uściślić: jest drogą do poznania rzeczywistości transcendentnej. We wspomnianych powieściach to (roz-)poznanie nie wiąże się z uczuciami afirmatywnymi, raczej ma negatywne konsekwencje dla podmiotu poznającego. Byt absolutny powołujący do istnienia światy, w których żyją bohaterowie, ma charakter skrajnie negatywny w związku z czym rzeczywistość, wykreowana przez ten byt, jest odwróconym demiurgicznym tworem mającym przypominać świat idealny.

\section{Alfred Kubin Po tamtej stronie - wizje chorego umysłu czy negatywna sila poznania?}

Alfred Kubin, austriacki rysownik i grafik, urodzony w czeskich Litomierzycach (1877-1959) kojarzony jest przede wszystkim jako autor niesamowitych, groteskowych i demonicznych w swoim wyrazie grafik i szkiców. Jak wspomina Paweł Huelle w Posłowiu do omawianej tu powieści Kubina, obrazy te „,na stałe weszły do repertuaru artysty, będąc zarówno treścią jego sztuki, jak i znakiem rozpoznawczym wysoce indywidualnego stylu" (Huelle 2008, s. 272). Huelle pisze również o polskim psychiatrze Antonim Kępińskim, który wszystkie te przerażające wizje Kubina zaliczył w poczet przestrzeni schizofrenicznej (Huelle 2008, s. 271). To doświadczenie schizofrenii, jak twierdzi Huelle, nie ograniczyło artyzmu Kubina, przeciwnie - otworzyło przed nim drogę do poznania własnej jaźni i pozwoliło wejść na ścieżkę duchowej, wręcz mistycznej, przemiany. O swoich doświadczeniach Kubin pisze w Autobiografii, która stanowi część powieści Po tamtej stronie.

Artysta odnotowuje w swoich wspomnieniach, że już od najmłodszych lat zainteresowany był tym, co przemijajace, przerażajace i odbiegające od normy. Niewątpliwie duży wpływ na tak postrzeganą rzeczywistość miały jego stosunki z ojcem, który po śmierci pierwszej, a potem drugiej żony całkowicie zamknął się w sobie i wycofał $\mathrm{z}$ aktywnego życia. Kubin pisze:

Ten [ojciec] żył sam na sam ze swym bólem i bezlitośnie mnie karał, nie sprawdzając, czy istotnie jestem winien - tak, że moje życie stało się nie do zniesienia. Ów czas całkowitego opuszczenia okazał się jednak niezwykle ożywczy dla mojej wyobraźni. Pławienie się w imaginacyjnych katastrofach, wybuchach pierwotnych, żywiołowych mocy, dawało mi zawsze wyraźne uczucie szczęścia, na kształt lekkiego upojenia, któremu towarzyszyły ciareczki wzdłuż kręgosłupa. Obserwowanie 
burzy, pożaru czy wezbranego dzikiego potoku należało do moich najwyższych rozkoszy. Byłem regularnym widzem bijatyk, aresztowań, targów bydła. [...] Palącą ciekawość wzbudzało we mnie także wiele jeszcze innych spraw. Na przykład zwłoki. [...] Stąd właśnie zrodziło się moje gwałtowne zainteresowanie podobnie straszliwymi scenami. Wypadki śmierci były dla mnie niepojęte i zdumiewające (Kubin 2008, s. 238-239).

Artysta coraz bardziej zanurzał się więc w otchłanie nie tylko świata, w którym żył, ale przede wszystkim w głębię własnej psychiki, skupiał się na emocjach, uczuciach i przeżyciach wewnętrznych, doprowadzając się często do ataków, jak sam to nazywał, delirium. Bardzo dużo czytał. Wielkie wrażenie zrobiła na nim w tym okresie przede wszystkim twórczość Schopenhauera. Istotnym momentem w życiu Kubina stało się poddanie hipnozie. Od tej chwili, jak sam pisze, stał się nerwowy, rozdrażniony i niespokojny. Postanowił popełnić samobójstwo:

[...] W tym celu, $\mathrm{z}$ tanim starym rewolwerem w kieszeni, pojechałem $\mathrm{w}$ dalekie strony mego dzieciństwa, by się zastrzelić na grobie matki. Tam na wszelki wypadek pomodliłem się, prócz Boga prosząc również matkę, by mi zesłała potrzebną moc i uchroniła przed tchórzostwem. Następnie doczekałem jeszcze do uderzenia dzwonu, w nadziei, że skądś nadejdzie pomoc. Ale nie nadeszła. Przyłożywszy lufę do prawej skroni, na której według tablicy anatomicznej zrobiłem zadrapanie szpilka, by nie chybić mózgu, pociągnąłem za cyngiel. Ale zardzewiała stara broń zawiodła, a zabrakło mi męstwa, by nacisnąć powtórnie - zrobiło mi się haniebnie mdło. Poleżałem kilka godzin w jakiejś gospodzie, po czym poszedłem do domu rodzinnego (Kubin 2008, s. 242).

Przez cały ten okres Kubin bardzo dużo rysował i stawał się powoli artystą rozpoznawalnym. Jakiś czas później nastąpił w jego życiu swego rodzaju przełom mistyczny, metafizyczny. Ta wewnętrzna przemiana Kubina, która wpłynęła na powstanie powieści Po tamtej stronie, mogła mieć związek z zakończeniem procesu indywiduacji. Proces ten dzieli się bowiem na dwa etapy: pierwszy - inicjacyjny polega na przystosowaniu się do rzeczywistości zewnętrznej (w przypadku Kubina pogodzenie się z ojcem, rozwój twórczy), natomiast etap drugi dotyczy rzeczywistości wewnętrznej i odnosi się do sfery symboli i archetypów. Takim właśnie symbolicznym, inicjacyjnym wydarzeniem w życiu Kubina stało się wysłuchanie koncertu w jednym $\mathrm{z}$ teatrów:

I tam zdarzyło mi się coś bardzo dziwnego psychicznie, a dla mnie decydującego, co do dziś niezupełnie pojmuję, chociaż wiele nad tym rozmyślałem. Kiedy mianowicie zaczęła grać niewielka orkiestra, ujrzałem z nagła całe otoczenie jaśniej a ostrzej, jakby w innym świetle. Na twarzach obecnych dokoła dostrzegłem znienacka zaskakującą zwierzoczłowieczość. Wszystkie dźwięki stały się osobliwie obce, wyzwolone ze swej przyczyny. Brzmiało mi to niczym jakaś szydercza, stękająca, dudniąca ogólna mowa, której nie rozumiałem, lecz która zdawała się mieć najwyraźniej jakiś całkiem widmowy, wewnętrzny sens. Posmutniałem, chociaż przenikała mnie jakaś szczególna błogość (Kubin 2008, s. 248).

Aby wyładować nadmiar emocji, które nie znalazły ujścia w twórczości artystycznej, Kubin zaczął spisywać swoje wizje i pomysły, z czego narodziła się opowieść o Państwie Snu. Książka ukazała się drukiem w 1909 roku wraz z ilustracjami autora. W swojej Autobiografii pisze on jeszcze:

Po tamtej stronie stanowi punkt zwrotny rozwoju duchowego i napomyka o tym skrycie i jawnie w wielu miejscach. Piszac ja, nabrałem dojrzałego rozeznania, iż nie tylko w dziwacznych, wzniosłych i komicznych momentach istnienia leżą najwyższe wartości, ale że to, co przykre, obojętne i powszednio-podrzędne, zawiera te same tajemnice. To, że pisałem zamiast rysować, leżało w naturze rzeczy, sposób pozbycia się szybciej napierających myśli był stosowniejszy, niż byłoby to możliwe inaczej (Kubin 2008, s. 257).

Wynikiem wszystkich nagromadzonych doświadczeń i emocji stała się powieść nietuzinkowa, posiadająca liczne odwołania filozoficzne, religijne i metatekstowe. Przede wszystkim całość fabuły ujęta została przez autora w ramy odnoszące się do znanego gnostyckiego, apokryficznego Hymnu o Perle, o czym będzie mowa później.

Powieść Kubina zaliczyć można do literatury fantastycznej o charakterze dystopijnym. Mamy tu do czynienia z dystopią czasu o charakterze retrospektywnym (Szacki 2000, s. 85-109), bowiem podstawą Państwa Snu jest zwrot ku temu, co było, ku przeszłości. Główny bohater przybywa do owego kraju na zaproszenie Klausa Patery władcy absolutnego stworzonego przez siebie państwa. 
Przestrzeń, którą kreśli w swojej powieści Kubin, jest nacechowana negatywnie, co staje się tłem późniejszej fabuły. Cały obszar Państwa Snu jest ograniczony i zamknięty, dzieli się na dzielnice, do których mają dostęp nieliczni. Pośrodku tego w zasadzie płaskiego terenu wznosi się stolica kraju - Perła, z górującym w niej pałacem Patery ten układ przestrzeni wymusza horyzontalny ruch postaci, które nie mogą dostać się pałacu Patery, co symbolizuje pewnego rodzaju zamknięcie na sferę sacrum, kojarzoną najczęściej z wertykalnością. Podkreśla to dodatkowo motyw izolacji od świata zewnętrznego, który przekłada się na opisy przyrody i zjawisk atmosferycznych. Nad krajem tym nigdy nie świeci słońce, w nocy nie widać gwieździstego nieba, a roślinność jest szara i zakurzona. Wszystko jest symboliczne i powierzchowne. Jak pisze Jan Kurowicki:

Dziwne to państwo. Życie jego obywateli toczy się w nim na niby. Pozornie kupuje się tam i sprzedaje, czyta gazety i załatwia osobiste i publiczne sprawy. Ale wszystko to jest symboliczne jakby dla zabawy (Kurowicki 1996, s. 113).

Państwo Snu jest rzeczywiście tworem dziwacznym, opierającym się przede wszystkim na gloryfikacji przeszłości. Całkowicie odizolowane od świata zewnętrznego, przyjmuje w poczet swych obywateli tylko ludzi wybranych, „niezadowolonych z nowoczesnej kultury”, którzy kierują się w swojej egzystencji jedynie wartościami duchowymi. Przybywający doń ludzie stanowią więc swego rodzaju elitę, wybranych i predestynowanych do zamieszkania w państwie Patery. Mieszkańcy są najczęściej uciekinierami ze swoich światów, w których nie umieli żyć, bądź tęsknili za życiem takim, jakie wiodło się w przeszłości (dystopia ucieczki). Ta idealizacja przeszłości ściśle wiąże się z koncepcją czasu. Jest to czas linearny, prowadzący głównego bohatera od wydarzenia do wydarzenia, a celem jego wędrówki po Państwie Snu (wędrówka ta przypomina wędrówkę poety po zaświatach w Boskiej Komedii) jest spotkanie z Paterą. Dodatkowo autor powieści konstruuje rzeczywistość, opierając ją na zestawieniu czasu świeckiego (codzienne życie mieszkańców głównie stolicy państwa - Perły) z czasem sakralnym. Ten ostatni ma swoje odbicie w dwóch elementach: motywie snu oraz motywie tzw. „Wielkiego Czaru Zegarowego".

Motyw snu w powieści Kubina rozdziela opisaną wyżej koncepcję czasu na czas realny i czas podświadomy, nierealny, w którym to mieszkańcy Perły jakby zamierają, zatrzymują się i zapadają w stan hibernacji. Czasem sakralnym natomiast, znajdującym się niejako poza ramami świadomego i podświadomego, objętym przez mieszkańców państwa całkowitym tabu, jest wspomniany „Wielki Czar Zegarowy”, o którym główny bohater pisze w liście przyjacielowi:

[...] Jest to pomieszczenie starego zegara, którego cyferblat zajmuje najwyższą, trzecią część wieży. Z tej tarczy, przezroczystej w nocy, odczytujemy dokładny czas i wszystkie zegary w mieście i kraju regulowane sa według niej. Nie byłoby w tym nic osobliwego, gdyby wieża ta nie miała ponadto pewnej zupełnie dziwacznej właściwości. Wywiera mianowicie na wszystkich mieszkańców tajemniczy, nieodparcie przyciągający wpływ. O określonych godzinach stare te mury otaczają tłumem mężczyźni i kobiety. Obcy przystaja zdziwieni, przygladajac się niepojętemu zachowaniu tego zgromadzenia. Ludzie drepcą nerwowo w miejscu i wciąż spoglądają na długie, zardzewiałe wskazówki w górze. Na zapytanie, co się tu dzieje, otrzymujesz roztargnione, wymijające odpowiedzi. Kto się przyjrzy jeszcze uważniej, dostrzeże dwa małe wejścia u podnóża wieży. Tam ciśnie sie wszystko. [...] Im dalej posuwają się wskazówki, tym bardziej wzrasta napięcie. Jeden po drugim znika; każdy chce pozostać w środku minutę lub dwie. Wychodzący mają wszyscy wyraz głębokiego zadowolenia, niemal szczęścia. [...] Podobno jest zgoła nieprzyzwoicie rozmawiać o tym i świadczy to o głupocie. [...] Wchodzi się do małej, wielokątnej pustej celi pokrytej częściowo zagadkowymi rysunkami, chyba symbolicznymi. Za murem słychać potężne wahadło w ruchu. Tik! tak... tak... tik... tak... Po kamiennej ścianie leje się woda, leje sie bez przerwy. Zrobiłem to, co człowiek, który wszedł przede mna: wpatrując się nieruchomo w ścianę powiedziałem wyraźnie i głośno: „Panie, oto stoję przed Tobą!’”. Potem znów się wychodzi. Moja twarz musiała mieć wyraz dość zaskoczony. [...] Ale rzecz najdziwniejsza: począwszy od dnia, kiedy zdobyłem się na to doświadczenie, odczułem, jak mnie także ogarnia przymus. Zrazu przechodząc koło wieży doznawałem tylko lekkiego wstrząsu, w następne dni mój niepokój wzrastał, po prostu pchało mnie do środka. [...] Według głównego wzoru porozstawiane są po całym mieście pomniejsze wieże. Podobno na wsi każde gospodarstwo musi mieć swój kąt zegarowy (Kubin 2008, s. 69-70).

Jak widać z powyższego opisu, wnętrze starego zegara stanowi sferę sacrum, która wyznacza czas metafizyczny oddziaływujący na 
mieszkańców Perły. „Wielki Czar Zegarowy” daje ponadto możliwość obcowania z bóstwem, zbliżenia się do niego, oddania jego opiece, co przypomina pewnego rodzaju rytuały inicjacyjne, podczas których przekracza się sferę profanum, by wkroczyć na drogę inicjacji w rzeczywistość poświęconą bóstwu. W omawianej powieści tym bóstwem jest Patera.

Władca absolutny i kreator rzeczywistości, Klaus Patera, jest tym, który zsyła na swoich poddanych sen. Dzięki temu może ich kontrolować i kierować nimi niczym marionetkami. Patera, pełen sprzeczności, dwoistości, jawi się jako Demiurg rządzący twardą ręką swoją krainą snu, ale ma też oblicze Boga Starotestamentowego:

[...] Blade oblicze okalały ciemne kędziory, powieki były szczelnie zamknięte, tylko usta drgały i poruszały się nieustannie, jakby chciały mówić. Jąłem z przejęciem podziwiać cudowną regularność i piękno tych rysów. Ze swym szerokim, niskim czołem i potężną nasadą nosa podobny był raczej bogom grackim niżeli żywemu człowiekowi. Na twarzy znaczył się głęboki ból. Wtem posłyszałem słowa, coś zaszeptało cicho i szybko:

- Uskarżasz się, że nigdy nie możesz przyjść do mnie, a ja przecież zawsze byłem przy tobie. Często widziałem, jak mi złorzeczyłeś i wątpiłeś we mnie. Co mam dla ciebie uczynić? Powiedz swoje życzenie! (Kubin 2008, s. 103)

Jest władcą o wielu twarzach, które ujawnia zgodnie z biegiem wydarzeń. To on decyduje o tym, kim będą mieszkańcy Państwa Snu, a wysyłając im swoje zaproszenie, łudzi ich wizją życia idealnego. Podstawowym wyznacznikiem egzystencji w państwie Patery jest osiągnięcie wiedzy absolutnej i poznanie wszechrzeczy. Patera to Demiurg, który, chcąc stworzyć świat doskonały, tworzy jego parodię, odwrotność. Wiedza, którą mają posiąść mieszkańcy tej krainy, a przede wszystkim główny bohater - monachijski rysownik, nie jest dla nich wyzwoleniem, nie przynosi szczęścia, staje się natomiast przekleństwem i obciążeniem ich bytu. Jest to bowiem wiedza o ich własnej naturze, o dwoistości tej natury i odwiecznym przyciąganiu się przeciwieństw.

Powieść Alfreda Kubina w dość oczywisty sposób nawiąuje m. in. do wspomnianego na początku utworu apokryficznego Hymn o perle. To gnostyckie dzieło w sposób metaforyczny i symboliczny opisuje podróż człowieka do źródeł swojej jaźni. Tytułowa perła jest symbolem wiedzy, którą zdobywa bohater - jest wiedzą o sobie samym, o istocie swojego bytu, o drodze, którą musi pokonać „oświecony”, ktoś, kto, poprzez swego rodzaju iluminację, osiągnął wyższy poziom rozwoju duchowego. W dziele Kubina główny bohater, tak jak książę z Hymnu o perle, dostaje wezwanie i zaproszenie do podróży w celu odnalezienia Perły - stolicy Państwa Snu, gdzie najważniejsze jest życie duchowe i wiedza. Bohater powieści przybywa więc do stolicy, zostawiając świat za sobą, odrywając się od tego, co było. Jego inicjacyjna droga przez zakamarki i labirynty Perły doprowadza ostatecznie do objawienia prawdy o jej władcy, ale i o sobie samym. W pewnym momencie okazuje się, że Patera może nie być rzeczywisty, być może jest jedynie woskową kukiełką, kierowaną, tak jak inni mieszkańcy państwa, niewidzialną ręka losu. W chwili, w której główny bohater zaczyna sie nad tym zastanawiać, następuje u niego wewnętrzna przemiana. Zaczyna dostrzegać dwoistość nie tylko władcy Państwa Snu, ale przede wszystkim dwoistość rzeczywistości i własnej natury. Potwierdza to słowa samego Kubina, który w Autobiografii pisał o licznych odwołaniach do własnych przeżyć, a przede wszystkim do filozofii Schopenhauera. Filozof ten twierdził, że świat jest tylko wyobrażeniem odbierającego go podmiotu (Świat jako wola $i$ wyobrażenie, 1819), Kubin ustami swojego bohatera mówi:

Coraz wyraźniej odczuwałem wspólną więź ze wszystkim. Wymienne stały się dla mnie barwy, wonie, tony i wrażenia smakowe. I wtedy pojąłem: świat to jest siła wyobraźni. [...] Bo teraz wiedziałem już przecież na pewno, że ruch wahadłowy w obie strony oznacza równowagę. [...] Teraz zrozumiałem Paterę, pana, straszliwego władcę. [...] Patera był wszędzie. Widziałem go tak w oczach przyjaciela, jak wroga, w zwierzętach, roślinach i minerałach. [...] Znajdowałem jednak i pierwiastki obce w sobie. Ku swemu przerażeniu bowiem wykryłem, iż moje, ,ja" składa się z niezliczonych ,ja”. [...] Każde z tych ,ja” miało własne poglądy. [...] Chcę radości więc chcę zarazem cierpienia. Nic - albo wszystko. W sile wyobraźni i nicości leżała zapewne praprzyczyna, a może stanowiły tożsamość. [...] Podobne odbicia we mnie rządziły teraz moim postępowaniem. Hałas świata zewnętrznego dopóty smagał moje nerwy, uczulając je, dopóki nie dojrzały do przeżyć Świata Snu. Przy końcu tego 
rozwoju kończy się człowiek jako istota poszczególna, nie jest też już więcej potrzebna. Ta droga prowadzi do gwiazd (Kubin, 2008, s. 128-130).

A więc tak naprawdę ten demiurgiczny wymiar rzeczywistości opisany przez Kubina w powieści Po tamtej stronie jest niczym innym, jak opisem zmagań autora (bohatera) z własnym wnętrzem, jest opisem wędrówki w głąb podświadomości, symbolem której jest Państwo Snu i Perła -źródło wiedzy, na poszukiwanie której wyruszył bohater, by ostatecznie dotrzeć do siebie samego oraz Patera. Kubin, poprzez zawiłą symbolikę i odwołania intertekstowe, wskazuje na zmagania z własną podświadomością i próbę dotarcia do swojej jaźni. Główny bohater to tak naprawdę alter ego Kubina. Błądząc po ulicach Perły, błądzi on po zakamarkach podświadomości pisarza, którą odzwierciedla w powieści postać Patery - zmiennego, niedostępnego, nieznanego władcy. Symbolem jaźni jest natomiast w utworze wielki zegar i jego czar. Wejście do niego i poddanie się „Wielkiemu Czarowi Zegarowemu" oznacza w rzeczywistości rozpoczęcie procesu indywidualizacji, docierania do jaźni. Poniekąd potwierdzają to słowa samego autora przedstawione $\mathrm{w}$ ostatnim cytacie $\mathrm{z}$ powieści i stanowią klucz do jej zrozumienia. Podkreślają dwoistość natury człowieka, a co za tym idzie jego pozytywne i negatywne oblicze. Ta wiedza rozczarowuje głównego bohatera, dla samego Kubina jest zaś odkryciem, kończącym etap inicjacyjny, pozwalającym pokonać mu etap przejściowy liminalny i przejść do sfery archetypów, które tak często są widoczne w twórczości artystycznej tego autora.

\section{Jan Weiss Mullerdom ma tysiąc pięter - rzeczywistość na granicy jawy i snu}

W analizowanej wcześniej powieści A. Kubina zauważalna była dystopia ucieczki i czasu, natomiast utwór Jana Weissa można zaliczyć przede wszystkim do dystopii polityki, którą cechują opis systemów totalitarnych oraz obrazy społeczności opartych na systemach policyjnego nadzoru i terroru (Szacki 2000, s. 62-63). Jedną z cech charakterystycznych dla antyutopii i dystopii jest poza tym to, że ob- razują one nie tylko zagrożenie totalitaryzmem, ale również zwracają uwagę na negatywne strony postępu technicznego, który spycha człowieka do roli marionetki. Na tle tak zdominowanego społeczeństwa (zdominowanego bądź przez władcę absolutnego, bądź przez postęp techniczny i cywilizacyjny) zawsze stoi wybitna jednostka (najczęściej główny bohater) obnażająca machinę napędzającą rzeczywistość, w której przyszło jej żyć. Tego rodzaju postacią jest w tym wypadku Piotr Brok, główny bohater powieści Weissa, którą Joanna Czaplińska nazywa pierwszą dystopią w literaturze czeskiej (Czaplińska 2001, s. 49).

Tak jak u A. Kubina obrazy na granicy snu i jawy wynikały z pewnych problemów psychicznych autora, tak w przypadku Weissa ich źródła można upatrywać w przeżyciach wojennych. Zaraz po wybuchu pierwszej wojny światowej Weiss znalazł się na froncie rosyjskim, w 1915 roku został wzięty do niewoli i osadzony w obozie Tockoje nazywanym obozem śmierci (Kmuníček 2012, s. 22-23). Przebywał tam do roku 1916. W obozie był świadkiem codziennej śmierci współwięźniów, tak w wyniku wycieńczającej pracy, jak i na skutek niedożywienia i chorób - przede wszystkim tyfusu. Majaczenia i sny, które wywoływała choroba, stały się również jego udziałem w momencie, kiedy sam na nią zapadł. Wizje chorego umysłu tak bardzo wbiły się w psychikę i pamięć Weissa, że przez całe późniejsze życie twórcze były stałym motywem jego utworów. W 1917 roku pisarz wstąpił do Legii Czechosłowackiej, następnie przez Władywostok, a potem Ukrainę i wschód Europy udało mu się szczęśliwie wrócić do kraju (w 1920 roku). Od momentu powrotu do Czechosłowacji Weiss zaczął zabiegać o różnego rodzaju kontakty literackie, co zaowocowało wydaniem pierwszych opowiadań dotyczących głównie przeżyć wojennych i legionowych. Ten pierwszy etap twórczości, niejako podsumowujący doświadczenia wojenne, zwłaszcza te psychiczne, zamknęła powieść Mullerdom ma tysiąc pięter. Jak podkreśla w swojej książce o Weissie Vilém Kmuníček, powieść ta łączy w sobie elementy dadaizmu i poetyzmu, jest gra z konwencją powieści detektywistycznej i fantastycznej, jednocześnie niesie niepokojące wizje 
przyszłości związane z drugą wojną światową (Kmuníček 2012, s. 151). Można w niej również dostrzec motywy związane z surrealizmem i psychoanalizą. Weiss skarżył się, pisze dalej Kmuníček, iż wydaną w 1929 roku powieść krytyka odebrała zbyt powierzchownie, a jej główna część kompozycyjna dotycząca konfrontacji snu i jawy pozostała przez większość niezrozumiana i pominięta (Kmuníček 2012, s. 36).

Podobnie jak w powieści Kubina, tak i tu można zauważyć pewnego rodzaju chwyt autora polegający na odwróceniu rzeczywistości. W powieści Po tamtej stronie odwrócony zostaje sens alegorycznego i symbolicznego Hymnu o perle, natomiast Weiss gra m. in. z symboliką religijną. Mullerdom, budowla o tysiącu pięter, jest swoistym państwem-miastem, którym rządzi bezwzględny Ohisver Muller. Ten gigantyczny dom wyrasta $z$ realnego świata, nie mając z nim jednak żadnych powiązań. Pozbawiony drzwi i okien, na rozkaz jego władcy, wciąż pnie się górę. Budynek podzielony jest na strefy zamieszkiwane przez ludzi umieszczanych w nim według schematów narzucanych przez jego twórcę. Są tu instytucje użyteczności publicznej, administracja, policja i Gedonia - znajdująca się w niższych partiach domu część przeznaczona tylko dla wybrańców. Jest to miejsce rozrywki i uciechy, tu znajdują się teatry, kościoły i luksusowe pałace. W Gedonii znajduje się ponadto giełda i targ niewolników, którzy wznosić będą kolejne piętra Mullerdomu. Anonimowi robotnicy wycieńczeni straszliwą pracą w krótkim czasie ślepną i są wysyłani na ostatnie, najwyższe piętra - żyją, pragnąc śmierci. Nad nimi mieszczą się już tylko więzienia.

Nad Gedonią znajduje się stupiętrowy oddział West-Wester, dzielnica kupców, sklepikarzy, przekupniów handlujących czym się da [...]. Tu wolno przepić pół pensji, tu szuka szczęścia zbiorowisko oszustów, złodziei, prowokatorów, szpiegów, zdrajców, spekulantów ulokowanych wedle majątku (im niżej, tym większy dobrobyt). [...] Na samym dole zaś tego wspaniałego gmachu przebywa Ohisver Muller, a $\mathrm{w}$ fundamentach mieści się gigantyczny skarbiec [...] (Magnuszewski 1995, s. 186-187).
Mullerdom jest zatem wysoką wieżą ciągle pnącą się w górę. Jest to swego rodzaju nawiązaniem do biblijnej wieży Babel, której budowniczy chcieli zbliżyć się do Boga, stawiając jej kolejne kondygnacje. W powieści Weissa widać jej odwrócony obraz. Najwyższe piętra stają się piekłem dla ich mieszkańców, natomiast uosobienie Boga/Demiurga-Ohisver Muller zamieszkuje dół budynku. Wieża w symbolice biblijnej może oznaczać symbol zbawienia (taki obraz jest zawarty w 2 Ks. Samuela, werset 22: 44-51, Biblia Gdańska: „On [Bóg] jest wieżą zbawienia"), ale wiąże się też ze znakiem pychy, pogardy i brakiem porozumienia. Natomiast w Boskiej Komedii Dantego przeczytać można w pieśni V nakaz: „Mocny jak wieża bądź, co się nie zegnie, chociaż się wicher na jej szczyty wali”. Te pozytywne i negatywne odwołania do symboliki wieży mają swój oddźwięk w powieści Weissa. Oto autor kreśli przed czytelnikiem obraz władcy absolutnego, którego poczynaniom towarzyszy przemoc, agresja i całkowity brak empatii. Jest on, wraz ze swoim tworem - Mullerdomem, uosobieniem pychy i pogardy. To on, jako jedyny prawodawca w swoim państwie, skazuje ludzi albo na śmierć, albo na zbawienie. Jednocześnie jego przeciwieństwem jest detektyw Piotr Brok, który dąży do zabicia tego samozwańczego władcy. Brok jest zatem w powieści postacią niosącą zbawienie, odwrotnością diabolicznego Ohisvera. Jednak również on w pewnym momencie ulega czarowi władzy i przypisuje sobie boskie właściwości. Kontestując swą niewidzialność, z pychą wykrzykuje:

Jak jsem mocný...! - Jako bůh! - Mohu učinit vše! - Stvořím zázraky, o jakých se nesnilo ani Kristu! Svět, zakletý do tohoto nebetyčného baráku, uvedu v úžas! - Mullerdóm - ted' patř́ mně! (Weiss 1964, s. 24).

Brok, uzurpując sobie boską siłę, znajduje się bardzo blisko granicy między rolą zbawiciela a despoty.

Ohisver Muller nakreślony jest przez autora powieści jako postać skrajnie negatywna. Nikt z ludzi zamieszkujących Mullerdom nie wie, jak naprawdę wygląda. Wśród bohaterów krążą opowieści, że jest on starym Żydem, młodym arystokratą lub staruszkiem tracącym kontakt z rzeczywistością. W ostatecznym spotkaniu Broka z Ohisve- 
rem okazuje się jednak, że bezwzględny władca jest małym, zakompleksionym człowieczkiem, autorem książki o torturowaniu kwiatów. Podobnie jak w powieści Kubina, wielki uzurpator okazuje się cieniem człowieka, kukłą, która kieruje jedynie nienawiść i rozpacz. Ohisver, uważany przez mieszkańców Mullerdomu za Boga, jest postacią demiurgiczną, której doskonały, w zamyśle, twór przynosi śmierć i zagładę. Interesujące, pod względem omawianej tu symboliki, jest także jego imię. Ohisver przywodzi na myśl innego bohatera, mianowicie Ahasvera - Żyda Wiecznego Tułacza zmuszonego za karę po wieczność wędrować światem. Według legendy, prawdopodobnie średniowiecznej, Ahasver popędzał Jezusa idącego na ukrzyżowanie. Za karę miał wiecznie wędrować w ubóstwie i bojaźni bożej, cechował się poza tym wielką mądrością, którą zdobywał, przez wieki wędrując światem. W powieści imię Ohisver stanowi jakby grę słowną, odwrotność imienia Ahasver i jest jego niezaprzeczalnym negatywnym odbiciem, któremu daleko do mądrości i bojaźni bożej.

Motywem, który również w pewien sposób łączy powieść Weissa i Kubina jest motyw snu, chyba najważniejszy motyw tej powieści; za jego pomocą Weiss stworzył całą mullerowską rzeczywistość. Sam autor niejednokrotnie, mówiąc o powieści, zwracał uwagę na ważny element kompozycji, którym były płynne przejścia przez dwie płaszczyzny - realności i snu. Także w tym wypadku można mówić o konwencji lustrzanego odbicia. Piotr Brok rzeczywistość Mullerdomu traktuje jako jawę, natomiast krótkie chwile omdlenia, utraty świadomości czy wizje zapadania w głęboki sen stanowią według niego przejście w świat iluzji - stanu w połowie sennego i koszmarnego. Powieść kończy jednak scena wyjaśniająca: oto okazuje się, iż cały Mullerdom z jego władcą i społecznością był tworem wyobraźni chorego na tyfus żołnierza. Wykorzystując elementy powieści fantastycznej, Weiss tak naprawdę powtarza znane już od wieków literaturze i filozofii pytanie: czym jest jawa, a czym sen? Czy życie nie jest snem, a jeśli tak, to kto go śni? Problematykę życia jako snu poruszało przed Weissem wielu twórców, wystarczy wspomnieć E. A. Poego, Novalisa, C. de la Barcę, czy teksty gnostyków. Również w literaturze czeskiej pisarze wcześniejsi zastanawiali się nad koncepcją rzeczywistości jako snu (np. L. Klíma, K. H. Mácha itd.). Weiss, poprzez fantastyczną fabułę, dodatkowo zadaje czytelnikowi pytanie o prawdę i fałsz, o relację między iluzją i deziluzją, rzeczywistością taką, jaką znamy, a tą, tworzoną przez nasz umysł. Postać Broka staje się łącznikiem między tymi dwoma sferami. Jest on bowiem zarówno biernym obserwatorem sennej rzeczywistości (jako chory żołnierz, któremu wszystko się śni), jak i jej głównym, dynamicznym aktorem odgrywającym rolę zbawcy.

Motyw snu Weiss wykorzystał, kreując również przestrzeń powieści. W dużej mierze przypomina ona estetykę surrealizmu. Przede wszystkim charakterystycznym rysem świata przedstawionego w powieści Weissa jest dynamizm i ograniczoność. Brok, jak i pozostali bohaterowie poruszają się w górę, bądź w dół tylko i wyłącznie po piętrach Mullerdomu. Charakterystyczne są (utrzymane w konwencji snu) nagłe zmiany akcji i odpowiadające im zmiany otoczenia, deformacja rzeczywistości, zmiany kształtów itp. Nad całością świata przedstawionego unosi się aura absurdalności i groteski, co jeszcze bardziej podkreśla chaos rzeczywistości i zło cechujące poczynania mieszkańców tego świata. Magnuszewski pisze o konwencji filmu ekspresjonistycznego:

Weiss, pisząc Mullerdom, świadomie i wiele skorzystał, podobnie jak w innych swoich utworach, z techniki ekspresjonistycznego filmu. Wyprawy Piotra Broka i towarzyszące im perypetie, błyskawiczne jazdy windami przez kilkaset pięter, gonitwy po korytarzach, ucieczki przed niebezpieczeństwami, przeplatane mniej dynamicznym epizodami, składają się na sekwencje obrazów szybko po sobie następujących bądź zwolnionych, ale zawsze trzymających w napięciu i wizualnie przyciągających (Magnuszewski 1995, s. 193).

W przestrzeń dynamiczną, reprezentującą ruch postaci, wkrada się momentami także przestrzeń statyczna, której zadaniem jest zatrzymać uwagę czytelnika na pewnych niuansach fabuły. Jedna i druga jest nacechowana negatywnie. Co istotne, obie przestrzenie można dodatkowo podzielić na przestrzeń wewnętrzną i zewnętrzną. Wewnętrzna dotyczy rzeczywistości Mullerdomu (cechuje ją umiarkowana statyczność i duża dynamiczność), natomiast zewnętrzna (cał- 
kowicie statyczna) odnosi się do sytuacji żołnierza znajdującego się w szpitalu, majaczącego w tyfusowej gorączce. Taka konstrukcja przestrzeni wpływa bezpośrednio na czas powieści

Mimo, iż czas biegnie w utworze linearnie, to w zestawieniu z pewną wertykalnością ruchu postaci, o którym była mowa już wcześniej, sprawia wrażenie chaotyczności. Poza warstwą odnoszącą się do czasu snu i jawy, można wyodrębnić także takie rodzaje czasu, jak czas przybycia bohatera i czas jego odejścia, czas oczekiwania i czas działania. Konwencja snu burzy momentami tę linearność (choćby wówczas, kiedy Weiss przedstawia przebłyski świadomości Broka znajdującego się w szpitalu wojskowym). To w pewien sposób dookreśla postać Broka, jak i rozwarstwienia na poziomie fabuły. Ponadto zaburzona jest linearność tekstu (czyli seria zdań), na co wskazują liczne odniesienia do treści reklam, plakaty, ogłoszenia, które w samej treści dzieła są wyodrębnione graficznie. Poprzez treści zawarte w tego typu wstawkach, czytelnik może sobie wyrobić dokładniejsza wizję życia w królestwie Ohisvera Mullera. Ten swoisty metaczas powieści podkreśla abstrakcję fabuły i ściśle nawiązuje do omawianej wcześniej koncepcji snu.

Demiurgiczne wymiary rzeczywistości przedstawione przez obu twórców opierają się zatem przede wszystkim na pewnej grze z czytelnikiem polegajacej na licznych odwołaniach do tekstów filozoficznych, religijnych i osiągnięć psychoanalizy. Estetyka analizowanych powieści w dużej mierze łączy się z surrealizmem, ekspresjonizmem i psychologizmem. Owa intertekstowość poniekąd zaciera ślad najważniejszy podczas analizowania tych utworów, łatwo bowiem przeoczyć odwołania do sfery głębszej niż świadomość - do sfery tego, co ukryte w podświadomości, a co w dużym stopniu wpływało na poczynania bohaterów i było swego rodzaju reprezentacją stanu umysłu Jana Weissa i Alfreda Kubina. Obaj bohaterowie ich powieści, przybysze z zewnątrz, wrzuceni w obce im środowisko, wędrując zaułkami i uliczkami, docierają ostatecznie do celu swoich poszukiwań - poznają prawdziwe oblicza władców tych krain - oblicza zmienne, dwoiste, wymykające się pewnym ustalonym normom. Kubin i Weiss kreślą ponadto obraz społeczeństwa podporządkowanego władcy absolutnemu, odzwierciedla to rzeczywistość świata przedstawionego ograniczona, zamknięta, odizolowana, w której centrum znajduje się perła - twórca tego świata na opak, w pierwotnym zamierzeniu mającym być światem doskonałym. Odkrycie i zrozumienie natury tej „perły” wiąże się z poczuciem rozczarowania, nie ze względu na zakończenie owej ekscytującej wyprawy w celu jej odnalezienia, ale raczej ze względu na niemożliwość jej konkretnego opisania, ze względu na odkrycie jej niejednoznaczności i dwoistości, co ostatecznie doprowadza do konkluzji, że miejsca akcji obu powieści to nie Państwo Snu i Mullerdom, ale psychika i podświadomość autorów omawianych tu dzieł.

\section{Literatura}

B a 1 M., 2012, Narratologia. Wprowadzenie do teorii narracji, tłum. A. Szwatoński i in., Kraków.

B 1 u m e n b e rg H., 2009, Praca nad mitem, thum. K. Najdek, M. Herer, Z. Zwoliński, Warszawa.

C zaplińska J., 2001, Dziedzictwo robota. Wspótczesna czeska fantastyka naukowa, Szczecin.

D o 1 e ž e 1 L., 2008, Studie z české literatury a poetiky, thum. B. Fořt, Praha.

H o d r o vá D., 2011, Chvála schoulení, Praha.

K m u ní č e k V., 2012, Hledání Jana Weisse, Liberec.

K u b in A., 2008, Po tamtej stronie, tłum. A. M. Linke, Kraków.

K u r o w i c k i J., 1996, Idealna biblioteka. Poradnik konesera, Zielona Góra.

Magnuszewski J., 1995, Stowiańszczyzna zachodnia $i$ południowa. Studia i szkice literackie, Warszawa.

N i et z s che F., 1911, Wola mocy. Próba przemiany wszystkich wartości (studia i fragmenty), thum. K. Drzewiecki, Warszawa.

P i ró g M., 1999, Psyche i symbol. Teoria symbolu Carla Gustava Junga na tle ujęć porównawczych rzeczywistości symbolicznej, Kraków.

S z a c k i J., 2000, Spotkania z utopia, Warszawa.

W e i s s J., 1964, Dům o tisici patrech, Praha.

Zwe iffel Ł., 2008, Utopia, idealna odpowiedź na nieidealna rzeczywistość, Kraków. 